\title{
Spectroscopic Sensing Characteristics of Novel Osmium Carbonyl Complexes to DNA and Other Polyanions
}

\author{
Gregory Ostner, Cody Piotrowski, Xinyao Ren, Yu Lei, Mehrun Uddin, \\ Stacey Wong, Karen Chen, Lan Pham, Elise Megehee, Enju Wang* \\ Department of Chemistry, St. John's University, Jamaica, USA \\ Email: *wange@stjohns.edu
}

How to cite this paper: Ostner, G., Piotrowski, C., Ren, X.Y., Lei, Y., Uddin, M., Wong, S., Chen, K.R., Pham, L., Megehee, E. and Wang, E.J. (2021) Spectroscopic Sensing Characteristics of Novel Osmium Carbonyl Complexes to DNA and Other Polyanions. American Journal of Analytical Chemistry, 12, 277-293.

https://doi.org/10.4236/ajac.2021.127017

Received: May 27, 2021

Accepted: July 5, 2021

Published: July 8, 2021

Copyright $\odot 2021$ by author(s) and Scientific Research Publishing Inc. This work is licensed under the Creative Commons Attribution International License (CC BY 4.0).

http://creativecommons.org/licenses/by/4.0/

\begin{abstract}
In this research, the absorbance and luminescence response of two osmium(II) phenathrane (phen) carbonyl complexes to various DNA, heparin and i-carrageenan polyanions were studied. The $\left[\mathrm{Os}(\mathrm{phen}){ }_{2} \mathrm{CO}(\mathrm{L})\right]^{2+}$ complexes with L either a 4-phenyl pyridine (4-phpy) or phenyl imidazole (phimd) group exhibit moderate luminescent intensity in the visible region, their intensities are highly altered by the addition of DNA and other polyanion samples. These luminescent responses to polyanions were also compared with the $\left[\mathrm{Ru}(\mathrm{phen})_{3}\right]^{2+}$ complex. In ethanol solution, the presence of polyanions significantly enhanced the luminescent emission intensity of $\left[\mathrm{Os}(\mathrm{phen})_{2} \mathrm{CO}(\mathrm{L})\right]^{2+}$ complexes with a blue shift. While the polyanions all showed emission enhancement on the highly luminescent $\left[\mathrm{Ru}(\mathrm{phen})_{3}\right]^{2+}$ complex in ethanol solution with a red spectra shift. The $\left[\mathrm{Os}(\mathrm{phen})_{2} \mathrm{CO}(\mathrm{L})\right]^{2+}$ with (phimd) ligand has the lowest emission in ethanol solution, its intensity can be enhanced up to 11 times in the presence of DNA polyanions. This enhancement for all the complexes in ethanol is mainly due to their electrostatic interaction with the anion sites and with some degree of ligand intercalation into the polyanion hydrophobic structure which reduced the solvent quenching of the complexes. The blue shift of the (4-phpy) and particularly (phimd) Os(II)CO complexes indicate an insertion of the (4-phpy) or (phimd) group into the polymer chains. The two new Os(II)CO complexes has great potential to be used as luminescence sensors for DNA and polyanion detection in the low micro molar range with high sensitivity.
\end{abstract}

\section{Keywords}

Os(II)CO Complex, Absorbance, Luminescence Spectroscopy, DNA and Polyanion Sensing 


\section{Introduction}

Deoxyribonucleic acid (DNA), heparin and carrageenan are natural anionic polymers produced in living systems. DNA is a polyanion made up of a repeating sequence of nucleotides which consist of nitrogen base pairs, sugar residue and phosphate groups. The phosphate groups on the DNA backbone give it an overall negative charge at neutral $\mathrm{pH}$. DNA is involved in the biological processes of nucleic acid replication, transcription and protein synthesis. The development of methods for DNA detection and DNA cleavage is a growing interest in the past few decades [1] [2] [3]. Heparin and carrageenan polyanions are composed of polysaccharides with sulfate and carboxylate anion groups. Heparin is widely used as an injectable anticoagulant in various clinical procedures, especially open-heart surgery [4]. It is often used within catheter lock solutions to maintain catheter potency to prevent thrombosis, or clotting. Overdose of this highly charged polyanion can cause adverse effects such as hemorrhaging [5] [6]. Thus, the quantity of this polyanion in the sample administered in medical procedures has to be strictly controlled. Carrageenan is a food additive used as a thickener found in ice cream, yogurt, and cottage cheese. Since an overdose of carrageenan has shown intestinal damage in some animals [7] [8], it is important to develop a sensor to determine the amount present in a given sample.

Positively charged $\mathrm{Ru}(\mathrm{II})$ and Os(II) polypyridyl complexes have gained great attention as DNA fluorescent structure probes or photosensitizers due to their high fluorescence emission changes upon binding/ligand intercalating with double stranded DNA [9]-[20]. 2,2'-bipyridine (bpy), 1,10-phenanthroline (phen), and imidazole derivatives as well as their more lipophilic analogs were intensively explored as ligands to study the metallocomplexes binding properties with DNA, and many of the DNA binding $\mathrm{Ru}(\mathrm{II})$ complexes have shown antiviral, or anti-cancer activity, through electrostatic binding, hydrogen bonding or intercalating into DNA duplexes as shown in many review papers [21] [22] [23] [24]. The ligand size, electronic and acid-base properties play important roles in the binding with DNA. When the complex bind through intercalating into DNA double helix major grove, its emission intensity increases along with a shift in the emission maximum. In particular, $\mathrm{Ru}$ (II) complex with (dipyrido[3,2a:2', $\left.3^{\prime}-c\right]$ phenazine (dppz) ligand is widely studied as switch-on probe for the quantitation and structural identification of DNA [13] [17] [18] [19]. Recently, the $\left[\mathrm{Ru}(\mathrm{phen})_{2}(\mathrm{dppz})\right]^{2+}$ complex was also studied as a luminescent switch-on sensor for the detection of heparin [25]. However, no work from other researchers has been done on the interaction of these metal complexes with carrageenan.

While $\left[\mathrm{Os}(\mathrm{phen})_{2}(\mathrm{dppz})\right]^{2+}$ is also a DNA light switching probe, its emission wavelength extends well into the infrared region [12]. We were interested in the photoluminescent property of $\left[\mathrm{Os}(\mathrm{phen}){ }_{2} \mathrm{CO}(\mathrm{L})\right]^{2+}$ complex series, where $\mathrm{L}$ is pyridine (py), 4-phenylpyridine (4-phpy) and triphenylphosphine $\left(\mathrm{PPh}_{3}\right)$ due to their moderate to high photo emission ability in the visible region and their emission changes when polyanions such as heparin, carrageenan and chondroi- 
tin sulfate are present [26] [27]. The $\left[\mathrm{Os}(\mathrm{phen}){ }_{2} \mathrm{CO}(4-\mathrm{phpy})\right]^{2+}$ (Structure in Figure 1) showed the highest luminescence enhancement by these polyanions in ethanol as well as in aqueous solutions. Our recent work extended the ligand L to include imidazole (imd), 3-phenylimidazole (phimd) (Figure 1) [28], and studied the response of these complexes to DNA samples of natural and synthetic resources beyond heparin and carrageenan. It was found that the response to the DNA samples was greatest with the (phimd) complex in ethanol solutions. This paper presents the results of spectral responses of the two best responsive OC(II)CO complexes towards DNA, heparin and carrageenan polyanions.

\section{Experimental}

\subsection{Materials and Instruments}

Ammonium hexachloroosmate (IV), trifluoromethanesulfonic acid (HOTf), potassium hexafluorophosphate $\left(\mathrm{KPF}_{6}\right)$, and 1,2-dichlorobenzene were purchased from Alfa Aesar. 1,10-phenanthroline monohydrate (phen) was purchased from Amresco. 1-phenylimidazole (phimd) was purchased from Matrix Scientific. 4-phenylpyridine (4-phpy), heparin sodium sulfate (H3393, >180 units/mg) (hep) derived from porcine mucosa, i-carrageenan ( $i$-carr), calf thymus DNA (double stranded (dsDNA-ct), single stranded (ssDNA-ct), and human DNA (dsDNA-h), and anhydrous ethanol (99.5\%), were obtained from Sigma-Aldrich. Synthetic single stranded DNA decamer (ssDNA-10) (sequence of CGCGAT CGCG) and synthetic double stranded DNA (dsDNA-10) (sequence of TTTGTCATTT) were purchased from Integrated DNA Technologies. Acetonitrile $\left(\mathrm{CH}_{3} \mathrm{CN}\right)$ was DriSolv grade and purchased from EMD Chemicals. Ethylene glycol was purchased from J. T. Baker. Dimethylsulfoxide- $d_{6}$ (DMSO) was purchased from Cambridge Isotope Laboratories. All other chemicals were commercially available products of the highest grade.

The ${ }^{1} \mathrm{H}$ NMR spectra were taken on a Bruker Ultra Shield $400 \mathrm{MHz}$ nuclear magnetic resonance spectrometer with d-DMSO as solvent. The ultraviolet-visible absorption spectra were taken on Thermo Insight UV-Vis spectrophotometer evolution 220. A luminescence spectrometer (LS-50 or 55, Perkin Elmer) was used for all the luminescence spectra measurements. Elemental analysis was conducted at Robertson Microlit Laboratories on new compounds.

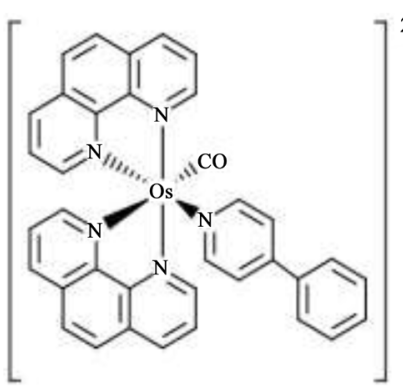

$\left[\left.\mathrm{Os}(\mathrm{phen})_{2} \mathrm{CO}(4-\mathrm{phpy})\right|^{2+}\right.$

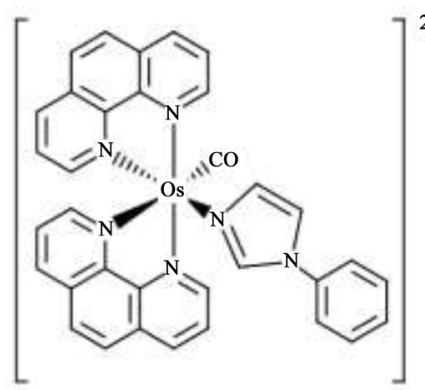

$\left\lceil\left.\mathrm{Os}(\text { phen })_{2} \mathrm{CO}(\right.$ phimd $)\right|^{2+}$

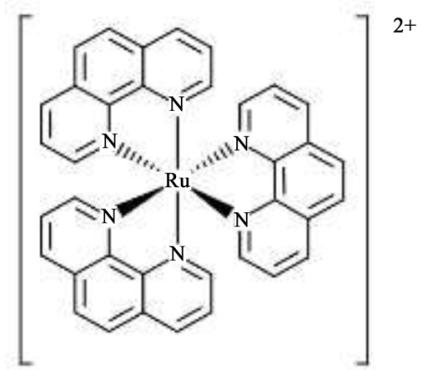

$\left[\operatorname{Ru}(\text { phen })_{3}\right]^{2+}$

Figure 1. Structure of the metallo-complexes. 


\subsection{Preparation of the $\left[\mathrm{Os}(\mathrm{phen})_{2} \mathrm{CO}(\mathrm{L})\right]\left(\mathrm{PF}_{6}\right)_{2}$ Complexes}

Os(phen $)_{2} \mathrm{Cl}_{2}$, cis-[Os(phen) $\left.{ }_{2} \mathrm{CO}(\mathrm{OTf})\right] \mathrm{OTf}$, and $\left[\mathrm{Os}(\mathrm{phen})_{2} \mathrm{CO}(4\right.$-phpy) $]\left(\mathrm{PF}_{6}\right)_{2}$ and $\left.\left.\mathrm{Ru}(\mathrm{phen})_{3}\right)\right]\left(\mathrm{PF}_{6}\right)_{2}$ were synthesized according to literature procedures [28] with purity $>98 \%$.

Synthesis of cis- $\left[\mathrm{Os}(\text { phen })_{2} \mathrm{CO}(\right.$ phimd $\left.)\right]\left(\mathrm{PF}_{6}\right)_{2}$ :

Cis-[Os(phen) $\left.{ }_{2} \mathrm{CO}(\mathrm{OTf})\right] \mathrm{OTf}$ (102.7 mg, $\left.0.117 \mathrm{mmol}\right)$, 1-phenylimidazole $(91.2 \mathrm{mg}, 0.633 \mathrm{mmol})$ and 1,2-dichlorobenzene $(8 \mathrm{~mL})$ were placed in a Schlenk flask and refluxed for 5 hours. The solid was purified via alumina column chromatography using 2:1 acetonitrile:toluene once as the mobile phase and then $5 \%$ methanol in acetonitrile. An orange solid was obtained with a yield of $50.2 \mathrm{mg}$ (0.0496 mmol, 42\%). ${ }^{1} \mathrm{H}$ NMR (dimethylsulfoxide- $d_{6}, 400 \mathrm{MHz}$ ): $\delta$ (ppm) 10.03 $\left(\mathrm{dd}, J_{1}=0.80 \mathrm{~Hz}, J_{2}=5.20 \mathrm{~Hz}, 1 \mathrm{H}\right), 9.19(\mathrm{~m}, 2 \mathrm{H}), 8.91(\mathrm{~d}, J=8.40 \mathrm{~Hz}, 1 \mathrm{H}), 8.84$ $(\mathrm{m}, 2 \mathrm{H}), 8.78(\mathrm{~d}, J=8.40 \mathrm{~Hz}, 1 \mathrm{H}), 8.52(\mathrm{~d}, J=8.80 \mathrm{~Hz}, 1 \mathrm{H}), 8.36(\mathrm{~m}, 4 \mathrm{H}), 8.27$ $\left(\mathrm{dd}, J_{1}=5.20 \mathrm{~Hz}, J_{2}=8.40 \mathrm{~Hz}, 1 \mathrm{H}\right), 8.10\left(\mathrm{dd}, J_{1}=1.00 \mathrm{~Hz}, J_{2}=5.40 \mathrm{~Hz}, 1 \mathrm{H}\right), 7.89$ $(\mathrm{t}, J=1.60 \mathrm{~Hz}, 1 \mathrm{H}), 7.78(\mathrm{~m}, 2 \mathrm{H}), 7.65\left(\mathrm{dd}, J_{1}=5.20 \mathrm{~Hz}, J_{2}=8.40 \mathrm{~Hz}, 1 \mathrm{H}\right), 7.60$ $(\mathrm{m}, 2 \mathrm{H}), 7.53(\mathrm{t}, J=7.80 \mathrm{~Hz}, 2 \mathrm{H}), 7.43(\mathrm{~m}, 1 \mathrm{H}), 7.11(\mathrm{~s}, 1 \mathrm{H}) .{ }^{13} \mathrm{C}$ NMR (dimethylsulfoxide- $\left.d_{6}, 100 \mathrm{MHz}\right): \delta(\mathrm{ppm}) 177.7,157.3,155.4,154.0,150.7,149.6$, $149.3,146.5,145.7,141.1,140.2,140.1,139.6,138.8,135.7,131.7,131.5,131.3$, $131.2,130.9,130.2,129.0,128.9,128.8,128.5,128.2,127.6,127.1,126.9,121.7$, 121.6. Anal. Calc. for $\mathrm{C}_{34} \mathrm{H}_{24} \mathrm{~F}_{12} \mathrm{~N}_{6} \mathrm{OOsP}_{2}$ : C, 40.32; H, 2.39; N, 8.30. Found: C, 40.03 ; $\mathrm{H}, 2.15$; N, $8.03 \%$.

\subsection{Preparation of the Stock Solutions}

The stock solutions of the $\mathrm{Os}(\mathrm{II}) / \mathrm{Ru}$ (II) complexes were prepared by dissolving $2.4 \mathrm{mg}$ of the complex in $100.00 \mathrm{~mL}$ deionized water or ethanol. Lower concentration solutions were diluted from the stocks. The $1.0 \mathrm{mg} / \mathrm{mL}$ solutions for different polyanions were prepared by dissolving $10.0 \mathrm{mg}$ of each polyanion in $10.00 \mathrm{~mL}$ deionized water. The $0.10 \mathrm{mg} / \mathrm{mL}$ and $0.010 \mathrm{mg} / \mathrm{mL}$ polyanion solutions were diluted from the $1.0 \mathrm{mg} / \mathrm{mL}$ solutions of the corresponding polyanion solutions with deionized water

\subsection{Spectral Measurement Procedures}

$U V$-Vis spectra. The ultraviolet-visible absorption spectra were taken on a Thermo Insight Evolution 220 double beam UV-Vis spectrophotometer, using a $1.0 \mathrm{~cm}$ quartz cuvette. Typically, $2.00 \mathrm{~mL}$ of the complex solution was placed in the cuvette, and a small aliquant of anion solutions were added into the cuvette. Immediately after a brief mixing, the absorbance of the solution mixture is recorded in the range of 250 to $500 \mathrm{~nm}$.

Luminescence measurements of the $O s(I I) / R u(I)$ complex solutions. $2.00 \mathrm{~mL}$ metal complex solution was transferred into a standard fluorescence quartz cuvette and placed in the cuvette holder. The emission and excitation slits were both set at $10 \mathrm{~nm}$. The excitation wavelength was set at $420 \mathrm{~nm}$ and luminescence spectra were recorded in the range of 450 to $750 \mathrm{~nm}$. The luminescence 
intensity at peak maximum was obtained and utilized for calculations and constructing calibration curves. All measurements were under ambient condition $\left(\sim 23^{\circ} \mathrm{C}\right.$ and in open air).

The luminescence response of the $\mathrm{Os}(\mathrm{II}) / \mathrm{Ru}(\mathrm{II})$ complexes to various polyanions was carried out by first obtaining the luminescence of the $2.00 \mathrm{~mL}$ complex solutions, then a small aliquant of ( 2 to $10 \mu \mathrm{L}$ ) of various DNA, heparin sodium salt or $i$-carrageenan was continuously added. The luminescence intensity of the $\mathrm{Os}(\mathrm{II}) / \mathrm{Ru}(\mathrm{II})$ complex solutions at a peak wavelength of each complex with successive additions was taken after each addition of polyanions. All the measurements were obtained immediately after the solution was mixed thoroughly.

\section{Response Principle and Data Treatment}

The osmium/ruthenium center in the complex is in the +2 oxidation state with an overall +2 charge on the complex ion. When the polyanions are present, the osmium complex could electrostatically bind to the anion sites and/or through ligand intercalation into the polyanion hydrophobic structure such as the double helix of DNA:

$$
z \mathrm{M}\left(\mathrm{L}_{6}\right)^{2+}+2 \mathrm{PLA}^{z-} \rightarrow\left(\mathrm{ML}_{6}\right)_{z}-(\mathrm{PLA})_{2}
$$

Here $\mathrm{M}\left(\mathrm{L}_{6}\right)^{2+}$ represents the six atom coordinated $\mathrm{Os}(\mathrm{II}) / \mathrm{Ru}(\mathrm{II})$ complex, $\mathrm{PLA}^{z-}$ represents the polyanion with a charge of $-z$. When bonded, the Os(II)/ $\mathrm{Ru}$ (II) complexes are close to the negative anion sites on the polyanion chain and some ligands may penetrate/intercalated into the cavity of the polyanion fold e.g. the DNA helix and the polyanion sugar chain that shield around the complex, therefore significantly changing the solvent environment around it, thus change its luminescence characteristics. Using $\alpha$ to represent the fraction of complexes bonded to the polyanions $\left(C_{\left(\mathrm{ML}_{6}\right)_{z}-\mathrm{PLA}}\right)$ relative to the total complex concentration $C_{0}, \alpha=\frac{C_{\left(\mathrm{ML}_{6}\right)_{2}-(\mathrm{PLA})_{2}}}{C_{0}}$, and the luminescence intensity of the complex in the free and bonded form as $F_{0}$ and $F_{b}$, respectively, the solution luminescence intensity in the presence of polyanions is given by:

$$
\begin{aligned}
& F=(1-\alpha) F_{0}+\alpha F_{b} \\
& \text { With } \alpha=\frac{F-F_{0}}{F_{b}-F_{0}}
\end{aligned}
$$

If the bonded form of the complex has a higher quantum yield, i.e. $F_{b}>F_{0}$, then $F$ is larger than $F_{0}$ when binding occurs. The luminescence intensity ratio $F / F_{0}$ can be expressed in terms of $\alpha$ :

$$
\frac{F}{F_{0}}=(1-\alpha)+\alpha \frac{F_{b}}{F_{0}}=\left(\frac{F_{b}}{F_{0}}-1\right) \alpha+1
$$

If the binding constant $K$ is large, when low polyanion concentration was added, all of the polyanions are bound to the Os(II) complex. The Os(II) com- 
plex concentration in the ion-pair is: $\mathrm{C}$

$$
\begin{gathered}
C_{\mathrm{Os}-\mathrm{PLA}}=\frac{z}{2} C_{\mathrm{PLA}} \text {, then } \alpha=\frac{Z C_{\mathrm{PLA}}}{2 C_{0}} \text {, and substituting into (3) we obtain: } \\
\frac{F}{F_{0}}=\left(\frac{F_{b}}{F_{0}}-1\right) \cdot \frac{z\left(C_{\mathrm{PLA}}\right)}{2 C_{0}}+1
\end{gathered}
$$

Plotting the ratio $\frac{F}{F_{0}}$ for the complex solution vs. the concentration of polyanion, $C_{\mathrm{PLA}}$ yields a linear curve with an intercept of 1 at low concentrations with no quenching by the polyanions. The slope of the curve, $\left(\frac{F_{b}}{F_{0}}-1\right) \cdot \frac{Z}{2 C_{0}}$ reflects the $\frac{F_{b}}{F_{0}}$ ratio, the effective binding charge $z$ of the polyanion, and the initial concentration of the complex $C_{0}$. The structure of the polyanions (helix vs. coil) and the ability to provide efficient intercalation of the complex into the polyanion shield determines $F_{b}$ (estimated from the concentrations of polyanion present that give the maximum enhancement: $F_{\max }$ ). The anion carrying group, number of charges and substitution groups on the disaccharide all contribute to variations in the binding strength, thus leading to different luminescent response slopes, and response ranges of the $\mathrm{Os}(\mathrm{II}) \mathrm{CO}$ and $\mathrm{Ru}(\mathrm{II})$ complex solutions to different polyanions. Smaller initial concentration $C_{0}$ results in a higher response slope of the $F / F_{0}$ vs the polyanion concentration curve.

\section{Results and Discussion}

\subsection{General Spectra of the Os(II)/Ru(II) Complexes}

From the absorption, excitation and emission spectra, the $\left[\mathrm{Os}(\mathrm{phen})_{2} \mathrm{CO}(4-\mathrm{phpy})\right]^{2+}$ complex has excitation peaks at 225, 270, 345 and $420 \mathrm{~nm}$, and emission peak at $\sim 560 \mathrm{~nm}$ in aqueous and ethanol solution. The peaks at 225, 270 and $345 \mathrm{~nm}$ are due to $\pi$ to $\pi^{*}$ transitions of the ligands, and the one at $420 \mathrm{~nm}$ is due to metal to ligand charge transfer as reported previously [28]. The emission intensity in ethanol is lower than in aqueous solution. Single and double strand DNA samples as well as other polyanions altered the absorbance and enhanced the luminescence of the $\left[\mathrm{Os}(\mathrm{phen})_{2} \mathrm{CO}(4 \text {-phpy) }]^{2+}\right.$ in solutions quite differently.

While substituting (4-phpy) with phenyl imidazole (phimd), the new Os(II)CO complex, $\left[\mathrm{Os}(\text { phen })_{2} \mathrm{CO} \text { (phimd) }\right]^{2+}$ has absorption/excitation peaks at 225,270 $\mathrm{nm}$ and small broad peaks around 360 and $425 \mathrm{~nm}$. The peaks at 225 and 270 $\mathrm{nm}$ are due to $\pi$ to $\pi^{*}$ transitions of the ligands, and the peaks at 360 and $425 \mathrm{~nm}$ are due to metal to ligand charge transfer. All excitation wavelengths result in one strong emission peak at $\sim 586 \mathrm{~nm}$ in aqueous and ethanol solution. The emission intensity in ethanol is lower than in aqueous solution. The emission at $586 \mathrm{~nm}$ is enhanced by single and double stranded DNA and other polyanions in ethanol as well as in aqueous solutions.

The $\left[\mathrm{Ru}(\text { phen })_{3}\right]^{2+}$ has absorption/excitation peaks at $225,270 \mathrm{~nm}$ and weak 
broad peak in the range of 330 to $520 \mathrm{~nm}$. The peaks at 225 and $270 \mathrm{~nm}$ are due to $\pi$ to $\pi^{*}$ transitions of the ligands, and the peak at $\sim 460 \mathrm{~nm}$ is due to metal to ligand charge transfer [9] [10] [11]. All excitation wavelengths result in one strong emission peak at $\sim 575 \mathrm{~nm}$ in aqueous and ethanol solution. The emission intensity in ethanol is lower than in aqueous solution. The emission at $575 \mathrm{~nm}$ is enhanced by single and double stranded DNA and other polyanions in ethanol solutions.

\subsection{Absorbance Spectra Changes in the Presence of Polyanions}

Addition of dsDNA to the $\left[\mathrm{Os}(\mathrm{phen})_{2} \mathrm{CO} \text { (phimd) }\right]^{2+}$ complexes in ethanol or aqueous solutions showed an increase in absorbance at $270 \mathrm{~nm}$, and the shoulder peak at 350 to $400 \mathrm{~nm}$. The UV-Vis spectra containing the [Os(phen) $)_{2} \mathrm{CO}$ (phimd) $]^{2+}$ complex only and the complex in the presence of dsDNA-ct is displayed in Figure 2(a). The DNA in solution absorbs at $258 \mathrm{~nm}$, thus the increase at $271 \mathrm{~nm}$ is the superimposition of the DNA absorbance over the $\pi$ to $\pi^{\star}$ transition of the $\left[\mathrm{Os}(\mathrm{phen})_{2} \mathrm{CO} \text { (phimd) }\right]^{2+}$ complex. The absorbance is slightly increased for the MLCT band from $350 \mathrm{~nm} 500 \mathrm{~nm}$ upon the addition of dsDNA-ct. The isosbestic point at $336 \mathrm{~nm}$ is apparent with the additions of dsDNA-ct. Similar results are obtained in aqueous solutions.

Additions of heparin and carrageenan to the $\left[\mathrm{Os}(\mathrm{phen}){ }_{2} \mathrm{CO}(\mathrm{phimd})\right]^{2+}$ complexes solutions showed similar pattern. The addition of $40 \mu \mathrm{g} / \mathrm{mL}$ heparin to [Os(phen) ${ }_{2} \mathrm{CO}$ (phimd) $]^{2+}$ ethanol solution caused a $6 \%$ decrease for the $\pi$ to $\pi^{*}$ transition absorption at $270 \mathrm{~nm}$. Similar spectral changes compared to the complex mixed with DNA were observed at the minor peaks of $336 \mathrm{~nm}$ and $423 \mathrm{~nm}$ with isosbestic point at $338 \mathrm{~nm}$ when heparin was added. Higher decrease (17\%) of the $\pi$ to $\pi^{*}$ absorbance was observed in aqueous solutions by additions of 40 $\mu \mathrm{g} / \mathrm{mL}$ of heparin. The presence of $20 \mu \mathrm{g} / \mathrm{mL}$ carrageenan caused an $18 \%$ of the reduction of the $\pi$ to $\pi^{*}$ absorption at $270 \mathrm{~nm}$ and a small increase at the MLCT bands in both ethanol and aqueous solutions. These small spectral changes indicate an inclusion/intercalation of the positively charged [Os(phen $)_{2} \mathrm{CO}($ phimd $\left.)\right]^{2+}$ complex into polyanion chain in ethanol and aqueous solutions facilitated by the electrostatic attraction of the polyanions to the $2+$ charge on the $\left[\mathrm{Os}(\mathrm{phen})_{2} \mathrm{CO}\right.$ (phimd) $]^{2+}$ complexes.

The presence of heparin or $i$-carrageenan in the $\left[\mathrm{Os}(\mathrm{phen})_{2} \mathrm{CO}(4-\text { phpy })\right]^{2+}$ complex solution showed a similar pattern. Figure 2 (b) shows an example of the spectral change of the $\left[\mathrm{Os}(\mathrm{phen})_{2} \mathrm{CO}(4-\mathrm{phpy})\right]^{2+}$ complex when heparin was successively added into the aqueous solution. There is a $20 \%$ (by heparin) and $30 \%$ (by $i$-carrageenan) decrease of the $\pi$ to $\pi^{\star}$ transition band at $270 \mathrm{~nm}$. An interesting spectral change is observed at the second ligand band around $360 \mathrm{~nm}$; there is an increase between 360 and $400 \mathrm{~nm}$, and a decrease between 290 and $360 \mathrm{~nm}$ with isosbestic points at 310 and $356 \mathrm{~nm}$. The MLCT band at $423 \mathrm{~nm}$ has a slight increase in absorption. Additions of DNA also showed similar spectral changes in the range of 300 to $500 \mathrm{~nm}$, corresponding to the second ligand 


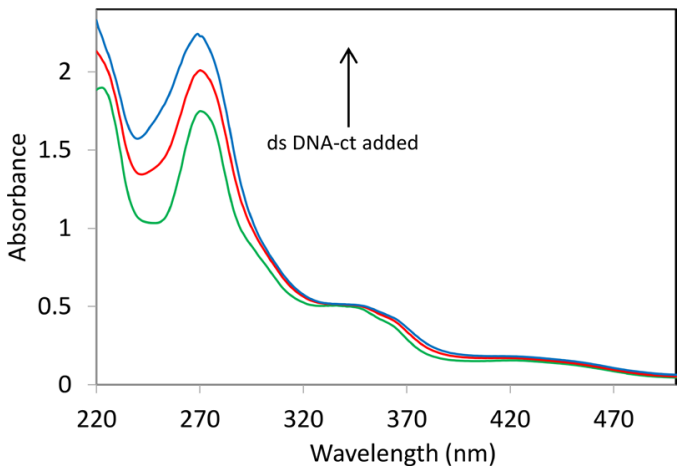

(a)

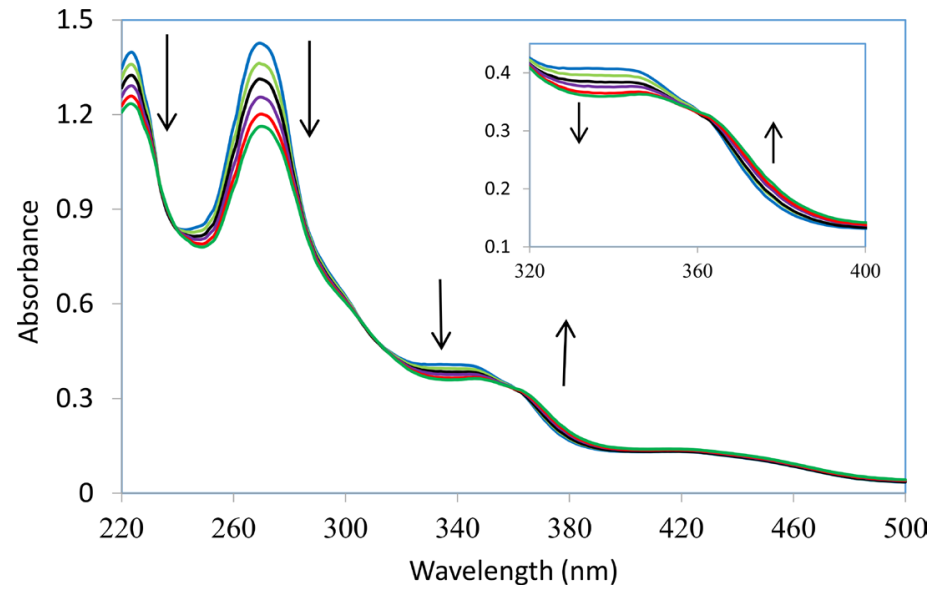

(b)

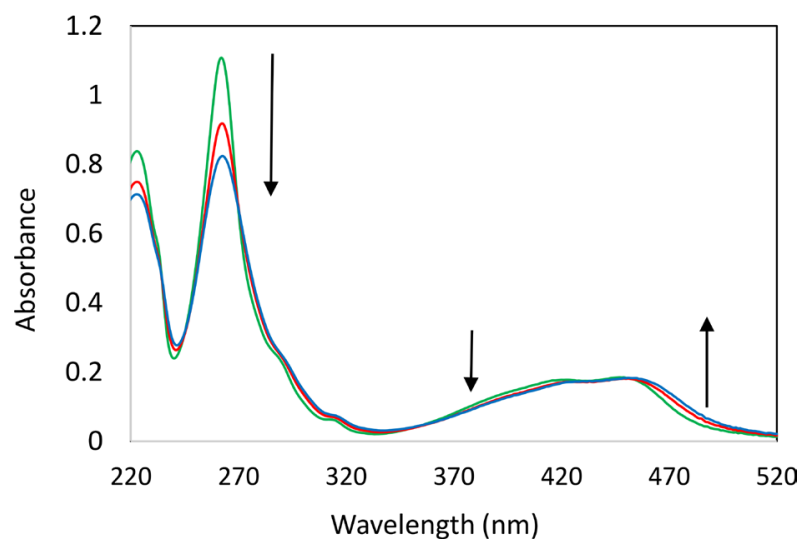

(c)

Figure 2. (a) Absorbance spectra of $[\mathrm{Os} \text { (phen) } 2 \mathrm{CO} \text { (phimd) }]^{2+}(24 \mu \mathrm{g} / \mathrm{mL})$ at $271 \mathrm{~nm}$ with $40 \mu \mathrm{g} / \mathrm{mL}$ (top, blue), $20 \mu \mathrm{g} / \mathrm{mL}$ (middle, red) and without (bottom, green) dsDNA-ct in ethanol solution. (b) Absorbance spectra of $\left[\mathrm{Os}(\mathrm{phen})_{2} \mathrm{CO}(4 \text {-phpy) }]^{2+}(24 \mu \mathrm{g} / \mathrm{mL})\right.$ at 271 $\mathrm{nm}$ (top green) successive additions of $2.5 \mu \mathrm{g} / \mathrm{mL}$ heparin in aqueous solution. Insert: absorbance spectra in the range of 320 to $400 \mathrm{~nm}$ with the same concentration of heparin in the solution. (c) Absorbance spectra of $\left[\mathrm{Ru}(\mathrm{phen})_{3}\right]^{2+}(24 \mu \mathrm{g} / \mathrm{mL}$ ) at $271 \mathrm{~nm}$ with 0 (top green) $5 \mu \mathrm{g} / \mathrm{mL}$ (middle, red) and $10 \mu \mathrm{g} / \mathrm{mL}$ (bottom, blue) $i$-Carr in aqueous solution.

band and the MLCT band. While there is a slight increase at the $270 \mathrm{~nm}$ peak, here the decrease of the $\pi$ to $\pi^{*}$ band is almost cancelled by the increasing DNA absorbance band. There is a $20 \%$ decrease of the complex-DNA mixture com- 
pared to the additives of the absorbance of the separate solutions of DNA and complex. Here again, the spectra of the 4-phpy complex in ethanol is similar to the absorbance band change in aqueous solutions, showing the binding pattern and strength is similar in both solvents between the complex and polyanions.

As a comparison, the spectral change of the $\left[\mathrm{Ru}(\mathrm{phen})_{3}\right]^{2+}$ complex in aqueous and ethanol solution was also obtained in the presence of the polyanions. Similar to the Os complexes, the $\pi$ to $\pi^{*}$ transition band at $270 \mathrm{~nm}$ is decreased, the MLCT band is slightly changed by carrageenan (see Figure 2(c)) and heparin, a decrease at $430 \mathrm{~nm}$ and isosbestic point at 360 and $454 \mathrm{~nm}$. While dsDNA samples did not change the ligand band at $270 \mathrm{~nm}$ due to its absorption, the effect on the MLCT band, e.g. a small decrease at $430 \mathrm{~nm}$ is similar to that observed by previous research [9] [10]. These were explained as being due to intercalation of the $\mathrm{Ru}(\mathrm{II})$ complex into the base pairs and surface binding along the helical grove.

These spectra changes indicate an intercalation of the positively charged complex into polyanion structures in ethanol and aqueous solutions to a similar degree. The changes at the ligand $\pi$ to $\pi^{*}$ is the smallest for all the polyanions to the $[\mathrm{Os} \text { (phen })_{2} \mathrm{CO}$ (phimd) $]^{2+}$ complex. Comparing $i$-carrageenan and heparin, $i$-carrageenan caused the largest decrease of absorption of the phen ligand band to all three complexes, indicating a stronger interaction with the complexes, this may be due to its higher number of charges per disaccharide (DS), thus a higher electrostatic binding with the cation complexes [7] [28].

\subsection{Luminescence Characteristics of the Metal Complexes in the Presence of Polyanions}

The two Os(II)CO complexes exhibit one broad luminescence peak in the range of 500 to $700 \mathrm{~nm}$ when excited at 270,350 or $420 \mathrm{~nm}$. The differences are that $\left[\mathrm{Os}(\text { phen })_{2} \mathrm{CO} \text { (phimd) }\right]^{2+}$ complex has a higher emission wavelength and much lower emission intensity than the $\left[\mathrm{Os}(\mathrm{phen})_{2} \mathrm{CO}(4 \text {-phpy) }]^{2+}\right.$ complex. The maximum emission intensity wavelength for each of the stock Os(II)CO solution in comparison to the $\mathrm{Ru}(\mathrm{II})$ complex is summarized in Table 1.

Shifts in emission maximum that occur upon changing solvent indicate emission from the metal-to-ligand charge transfer state for transition metal complexes. Polar solvents shift emission to lower energy (longer wavelengths) as a result of stabilization of the excited state dipole moment through solvent relaxation, and therefore longer lifetimes of the excited state of the molecule [11]. This

Table 1. Maximum emission peak wavelength for the $24 \mu \mathrm{g} / \mathrm{mL}$ Os(II)-CO and $\mathrm{Ru}(\mathrm{II})(\mathrm{phen})_{3}$ complexes.

\begin{tabular}{ccccccc}
\hline \multirow{2}{*}{ Complex Solvent } & \multicolumn{2}{c}{ Os $\left[(\text { phen })_{2} \mathrm{CO}(4 \text { phpy })\right]^{2+}$} & \multicolumn{2}{c}{$[\text { Os(phen })_{2} \mathrm{CO}($ Phimd $\left.)\right]^{2+}$} & \multicolumn{2}{c}{$\left[\mathrm{Ru}(\text { phen })_{3}\right]^{2+}$} \\
\cline { 2 - 7 } & EtOH & aq & EtOH & aq & EtOH & aq \\
\hline Emission Peak $(\mathrm{nm})$ & 567 & 563 & 588 & 585 & 575 & 574 \\
Intensity & 221 & 387 & 48 & 77 & 143 & 331 \\
\hline
\end{tabular}


trend was observed with the Os(II)CO complexes, there is a small blue shift in emission maximum changing from ethanol to the more polar aqueous solutions. $\left[\mathrm{Ru}(\mathrm{phen})_{3}\right]^{2+}$ complex showed no blue shift of the emission peak wavelength in aqueous than in ethanol as shown in Table 1. All three complexes showed higher emission in aqueous solutions, indicating that the ethanol solvent has higher quenching efficiency to the complex luminescence than water molecules. The three complexes all showed emission enhancement by polyanions, dsDNA, $i$-carrageenan and heparin in both aqueous and ethanol solutions.

Figure 3(a) \& Figure 3(b) show the emission spectra of the two Os(II)CO complexes in ethanol with continuous additions of dsDNA-h samples. The initial peak wavelength of the $\left[\mathrm{Os}(\text { phen })_{2} \mathrm{CO} \text { (phimd) }\right]^{2+}$ complex in ethanol solution was $588 \mathrm{~nm}$. As dsDNA-h was added, the maximum peak wavelength shifted to a shorter wavelength of $570 \mathrm{~nm}$. This $\Delta \lambda$ of $-18 \mathrm{~nm}$ blue shift indicates the presence of the DNA strand increased the electronic transition energy of the luminescence of $\left[\mathrm{Os}(\mathrm{phen})_{2} \mathrm{CO} \text { (phimd) }\right]^{2+}$ complex. The luminescent intensity enhancement at the peak can be as high as 10 times with DNA concentrations in the range of 1 to $40 \mu \mathrm{g} / \mathrm{mL}$. Single strand DNA, carrageenan and heparin also show strong emission enhancement with blue shift.

As shown in Figure 3(b), the addition of DNA sample also induced an emission enhancement with a blue shift of the emission wavelength for the (4-phpy) complex. Compare to the (phimd) complex, the enhancement ratio at the peak wavelength is smaller ( $\sim 5$ times).

In comparison, Figure $3(\mathrm{c})$ shows the emission spectra of the $\left[\mathrm{Ru}(\mathrm{phen})_{3}\right]^{2+}$ complex in the addition of ssDNA-ct samples in ethanol. There is a gradual increase in luminescence intensity with ssDNA-ct concentration up to $140 \mu \mathrm{g} / \mathrm{mL}$ at $575 \mathrm{~nm}$. Different from the two Os(II)CO complexes, the emission spectra has a red shift of $\sim 5 \mathrm{~nm}$. Double stranded DNA as well as $i$-carrageenan and heparin also show the emission intensity enhancement with small red shifts. This is similar to the earlier works that the presence of dsDNA in the $\left[\mathrm{Ru}(\mathrm{phen})_{3}\right]^{2+}$ complex in aqueous solution induce luminescence enhancement with a slight red shift, which is due to the intercalating of the (phen) ligand through stacking into the dsDNA base pairs and also the electrostatic interaction at the surface with the DNA anion groups [9] [10] [11].

The two Os(II)CO complexes show enhancement with added polyanions up to a certain maximum concentration, then the emission intensity started to decrease due to quenching by the anion sites. To compare the luminescence enhancement characteristics of the three complexes to the various polyanions, the $\mathrm{F}_{\max } / \mathrm{F}_{\mathrm{o}}$ ratio and the emission maximum shift were obtained for each complexes with the gradual addition of polyanions in two solvents and summarized in $\mathrm{Ta}$ ble 2 and Table 3. Overall, the luminescence emission enhancement was greater in the ethanol solution compared to the corresponding values in aqueous solution. The Os(II)CO complexes showed blue shifts, while Ru complex is red shifted in ethanol. The blue shift and the emission intensity enhancement are 


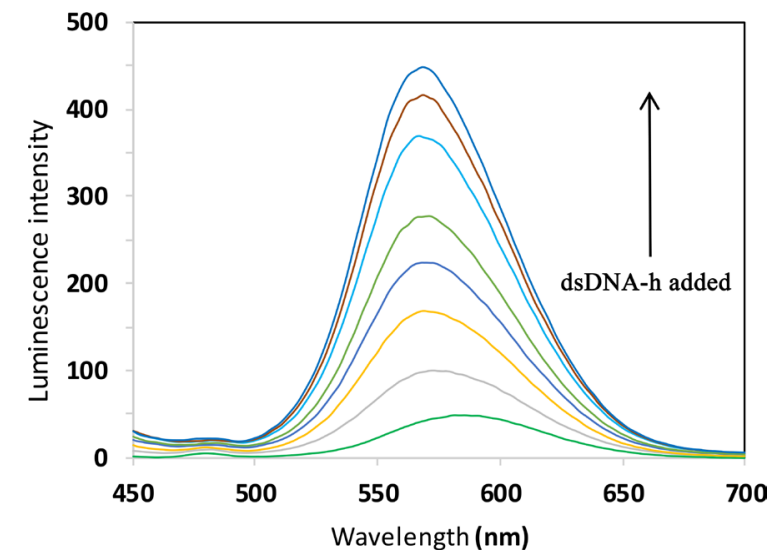

(a)

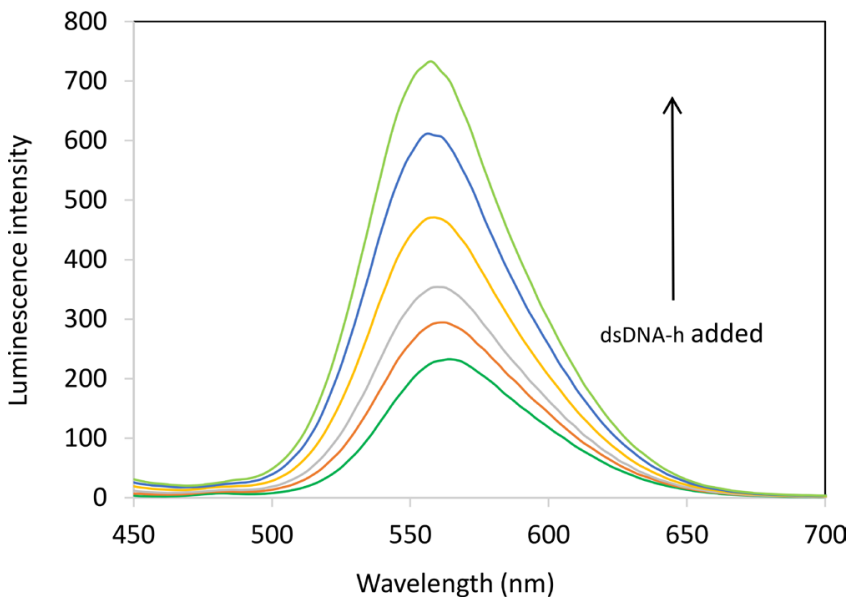

(b)

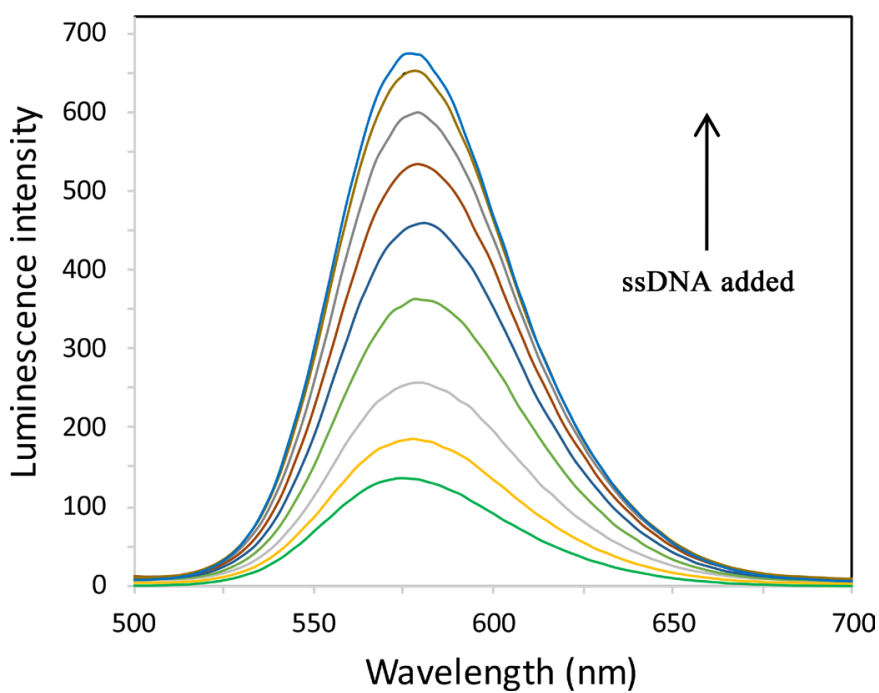

(c)

Figure 3. (a) Luminescence spectra of $\left[\mathrm{Os}(\mathrm{phen}){ }_{2} \mathrm{CO} \text { (phimd) }\right]^{2+}(24 \mu \mathrm{g} / \mathrm{mL})$ ethanol solution with addition of $0,10,20,30,40,60,80,100 \mu \mathrm{L}$ of $1 \mathrm{mg} / \mathrm{mL}$ dsDNA-h. (b) Luminescence spectra of $\left[\mathrm{Os}(\mathrm{phen}){ }_{2} \mathrm{CO}(4-\mathrm{phpy})\right]^{2+}(24 \mu \mathrm{g} / \mathrm{mL})$ ethanol solution with addition of 0 , $5,10,20,30,40 \mu \mathrm{L}$ of $1 \mathrm{mg} / \mathrm{mL}$ dsDNA-h. (c) Luminescence spectra of $\left[\mathrm{Ru}(\mathrm{phen})_{3}\right]^{2+}(24$ $\mu \mathrm{m} / \mathrm{mL}$ ) (bottom) in ethanol solution with successive addition of 10 (spectra 2 bottom) or $20 \mu \mathrm{L}$ of $1 \mathrm{mg} / \mathrm{mL}$ ssDNA-ct. 
Table 2. Luminescence maximum wavelength change and the enhancing ratio of complexes in ethanol solutions $(24 \mu \mathrm{g} / \mathrm{mL})$ by polyanions.

\begin{tabular}{ccccccc}
\hline Complex & item & ssDNA-ct & dsDNA-ct & dsDNA-h & Carr & Heparin \\
\hline$\left[\mathrm{Os}(\text { phen })_{2} \mathrm{CO}(\text { phimd })\right]^{2+}$ & $\Delta \lambda$ & -14 & -9 & -18 & -15 & -13 \\
& $\mathrm{~F}_{\max } / \mathrm{F}_{0}$ & 11.5 & 8.5 & 10.7 & 8.0 & 4.7 \\
{$\left[\mathrm{Os}(\text { phen })_{2} \mathrm{CO}(4-\mathrm{phpy})\right]^{2+}$} & $\Delta \lambda$ & -6 & -4 & -7 & -15 & -13 \\
& $\mathrm{~F}_{\text {max }} / \mathrm{F}_{0}$ & 6.4 & 5.5 & 5.5 & 5.0 & 4.8 \\
{$\left[\mathrm{Ru}(\text { phen })_{3}\right]^{2+}$} & $\Delta \lambda$ & 4 & 4 & 5 & 3 & 5 \\
& $\mathrm{~F}_{\text {max }} / \mathrm{F}_{0}$ & 5.1 & 5.2 & 6.1 & 4.0 & 2.2 \\
\hline
\end{tabular}

Table 3. Luminescence maximum wavelength change and the enhancing ratio of complexes in aqueous solutions $(24 \mu \mathrm{g} / \mathrm{mL})$ bypolyanions.

\begin{tabular}{ccccccc}
\hline Complex & item & ssDNA-ct & dsDNA-ct & dsDNA-h & Carr & Heparin \\
\hline$\left[\mathrm{Os}(\mathrm{phen})_{2} \mathrm{CO}(\mathrm{phimd})\right]^{2+}$ & $\Delta \lambda$ & 0 & -3 & -10 & -6 & 0 \\
& $\mathrm{~F}_{\max } / \mathrm{F}_{0}$ & 1.7 & 1.4 & 2.4 & 4.0 & 1.7 \\
{$\left[\mathrm{Os}(\mathrm{phen})_{2} \mathrm{CO}(4-\mathrm{phpy})\right]^{2+}$} & $\Delta \lambda$ & 5 & 6 & 5 & 0 & 0 \\
& $\mathrm{~F}_{\max } / \mathrm{F}_{0}$ & 2.1 & 1.7 & 1.7 & 3.0 & 2.2 \\
{$\left[\mathrm{Ru}(\mathrm{phen})_{3}\right]^{2+}$} & $\Delta \lambda$ & 3 & 4 & 5 & 4 & 3 \\
& $\mathrm{~F}_{\max } / \mathrm{F}_{0}$ & 1.2 & 2.0 & 2.0 & 1.8 & 1.2 \\
\hline
\end{tabular}

higher with the $\left[\mathrm{Os}(\mathrm{phen}){ }_{2} \mathrm{CO} \text { (phimd) }\right]^{2+}$ complex in ethanol solution. Double stranded human DNA and $i$-carrageenan showed the highest responses in both ethanol and aqueous solutions with all three complexes. In aqueous solution, the luminescence enhancement by the polyanions are much smaller, DNA samples exhibited smaller response than $i$-carr with the Os(II)CO complexes, and the ssDNA response is the smallest indicating a very small interaction of the $\mathrm{Os}(\mathrm{II}) \mathrm{CO}$ complex with this polyanion in aqueous solutions. These indicate that the dsDNA has a higher binding ability with the complexes in aqueous solutions which may due to its double helix structure that favored the intercalation with the double charged complexes.

The blue shift of the Os(II)CO complexes in ethanol solution with the presence of polyanions may be due to that the sixth ligand (4-phpy) or (phimd) extends out and penetrate into the polymer hydrophobic area, thus protected from ethanol solvent molecular collisional quenching. Particularly Os(II)CO complexes with (phimd) ligand, there is blue shift in aqueous solutions with dsDNA presence. This may be owing to the $\mathrm{N}$ atom on the (phimd) enhanced interaction with DNA, thus the complex emission experiencing blue shift in both solvents. This may also contributes to the high enhancement ratio of the (phimd) complex in ethanol by the DNA samples in ethanol.

Response curves with the enhancement ratio $\left(\mathrm{F} / \mathrm{F}_{\mathrm{o}}\right)$ of the complexes vs. the concentration of the polyanions are plotted. The curves for the $\left[\mathrm{Os}(\mathrm{phen}){ }_{2} \mathrm{CO}\right.$ (phimd) $]^{2+}$ complexes in ethanol show the highest slopes to the respective po- 
lyanions reported here and they are shown in Figure 4. DNA samples, double or single stranded, showed much high response than carrageenan and heparin in ethanol. There is a linear response in the low concentration ranges tested for each polyanions. These responses are much higher than with $\left[\mathrm{Os}(\mathrm{phen})_{2} \mathrm{CO}(4-\mathrm{phpy})\right]^{2+}$ and $\left[\mathrm{Ru}(\mathrm{phen})_{3}\right]^{2+}$ in ethanol solutions (see Figure 5 for dsDNA response). The response ranges and the slopes for these three complexes to four polyanions are summarized in Table 4. These data indicate that the complexes have great potential

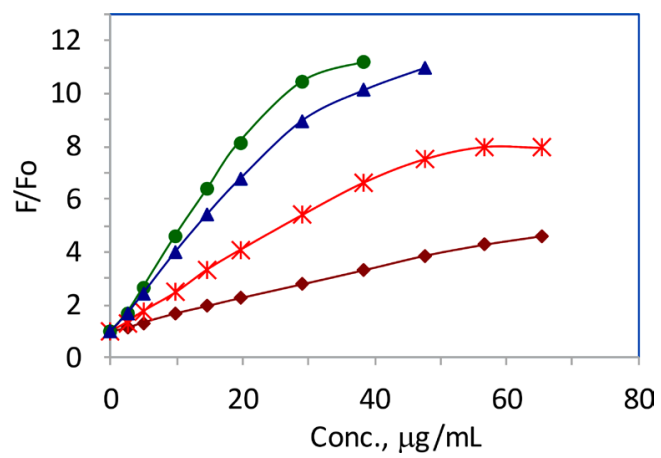

Figure 4. Fluorescence ratio $\left[\mathrm{Os}(\mathrm{phen})_{2} \mathrm{CO}(\mathrm{Phimd})\right]^{2+}(24 \mu \mathrm{g} / \mathrm{mL})$ plotted against the concentration of various polyanions in ethanol solution. $(\bullet) \operatorname{ssDNA}-\mathrm{ct},(\boldsymbol{\Delta}) \mathrm{dsDNA}-\mathrm{h},(\mathbf{X})$ Carr, $(\diamond)$ Hep.

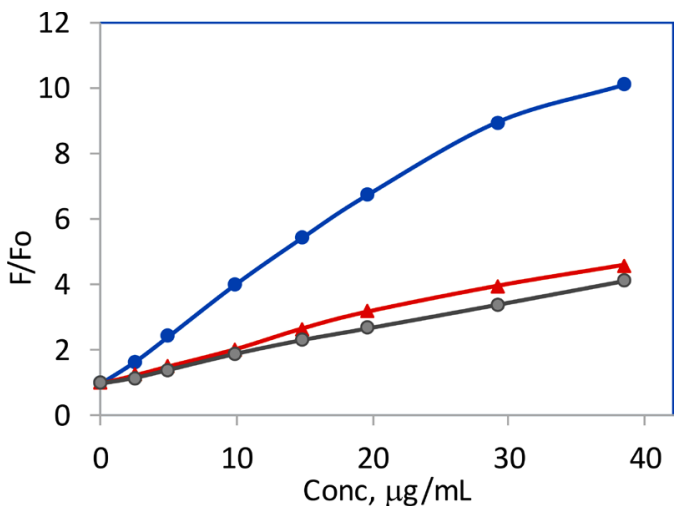

Figure 5. Human DNA response at three complexes in ethanol solution. $(\bullet)[\mathrm{Os}(\mathrm{ph}-$ en $)_{2} \mathrm{CO}($ phimd $\left.)\right]^{2+},(\Delta)\left[\mathrm{Os}(\text { phen })_{2} \mathrm{CO}(4 \text {-phpy })\right]^{2+},(\bullet)\left[\mathrm{Ru}(\text { phen })_{3}\right]^{2+}$.

Table 4. Response range of the metallo-complexes $(24 \mu \mathrm{g} / \mathrm{mL})$ to polyanions in ethanol solutions.

\begin{tabular}{|c|c|c|c|c|c|c|}
\hline Complexes & item & ssDNA-ct & dsDNA-ct & dsDNA-h & Carr & Heparin \\
\hline \multirow{2}{*}[\mathrm{Os}(\text{phen})_{2}\mathrm{CO}(\text{phimd})]{$^{2+}$} & $\begin{array}{l}\text { Linear range } \\
\quad(\mu \mathrm{g} / \mathrm{mL})\end{array}$ & $1-30$ & $1-32$ & $1-32$ & $1-45$ & $1-70$ \\
\hline & Slope & 0.34 & 0.20 & 0.20 & 0.15 & 0.067 \\
\hline \multirow[t]{2}{*}[\mathrm{Os}(\text{phen})_{2}\mathrm{CO}(4\text{-phpy})]{$^{2+}$} & $\begin{array}{l}\text { Linear range } \\
\quad(\mu \mathrm{g} / \mathrm{mL})\end{array}$ & $1-20$ & $1-30$ & $1-30$ & $1-30$ & $1-38$ \\
\hline & Slope & 0.12 & 0.13 & 0.095 & 0.14 & 0.077 \\
\hline \multirow[t]{2}{*}[\mathrm{Ru}(\text{phen})_{3}]{$^{2+}$} & $\begin{array}{l}\text { Linear range } \\
\quad(\mu \mathrm{g} / \mathrm{mL})\end{array}$ & $1-80$ & $1-80$ & $1-80$ & $1-80$ & $1-90$ \\
\hline & Slope & 0.060 & 0.082 & 0.082 & 0.067 & 0.027 \\
\hline
\end{tabular}


to be used for the sensitive luminescent determination of these polyanions in ethanol solution. As shown in Figure 6, in aqueous solution, the dsDNA response range is similar with all three complexes, indicating the degree of interaction of the complexes with dsDNA are similar.

Concentration dependent studies show that the response range moves to lower anion concentration when lower complex concentrations are used. As predicted by equation 4 , lowering the complexes concentration, $C_{0}$, would increase the response slope. When concentrations of the complexes were reduced from 24 to $12,9.6$ or $4.8 \mu \mathrm{g} / \mathrm{mL}$, the response curve gradually shifted to the lower concentration ranges. With the same complexes, similar spectral shifts and maximum enhancement ratio were obtained, however, at lower concentration, the enhancement ratio increased much more rapidly. Table 5 listed the response ranges at $4.8 \mu \mathrm{g} / \mathrm{mL}$ of the $\mathrm{Os}(\mathrm{II}) \mathrm{CO}$ complexes in ethanol solution. Compared to Table 4, the response ranges are much narrower, while the slopes are higher. Table 5 also shows that the synthetic short chain ssDNA-10 has much smaller response while the dsDNA-10 give the highest maximum enhancement and highest slope for the (phind) Os(II)CO complex. The concentration dependent enhancement is a clear indication that the complexes bind to the polyanions in solutions tightly and rapidly, that the binding equilibrium exists at each addition of polyanions, and that the bond complexes exhibit higher emission quantum yield.

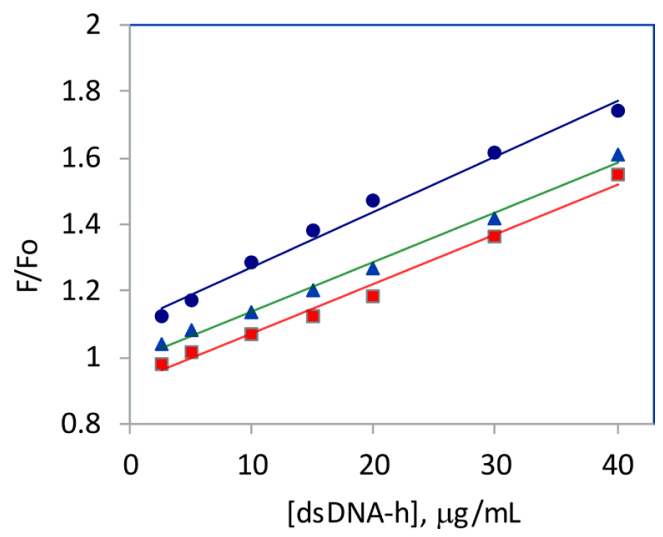

Figure 6. Fluorescence ratio $(\bullet)\left[\mathrm{Os}(\text { phen })_{2} \mathrm{CO}(\mathrm{Phimd})\right]^{2+},(\Delta)\left[\mathrm{Ru}(\mathrm{phen})_{3}\right]^{2+}$ and $(\square)$ $\left[\mathrm{Os}(\text { phen })_{2} \mathrm{CO}(4-\text { phpy })\right]^{2+}$ complex $(24 \mu \mathrm{g} / \mathrm{mL})$ plotted against the concentration of dsDNA-h polyanions in aqueous solution.

Table 5. Response ranges and average slope values of OsCO(II) complexes with polyanions in ethanol ( $2.00 \mathrm{~mL}$ of $4.8 \mu \mathrm{g} / \mathrm{mL}$ complex solution in cuvette).

\begin{tabular}{|c|c|c|c|c|c|c|c|}
\hline Complex & Item & ssDNA-ct & dsDNA-h & ssDNA-10 & dsDNA-10 & $i$-carr & heparin \\
\hline \multirow{2}{*}[\mathrm{Os}(\text{phen})_{2}\mathrm{CO}(\text{phimd})]{$^{2+}$} & $\begin{array}{l}\text { Response Range } \\
(\mu \mathrm{g} / \mathrm{mL})\end{array}$ & $1-15$ & $0.5-15$ & $4-7$ & $1-20$ & $0.5-15$ & $0.5-15$ \\
\hline & Linear range Slope & 0.71 & 0.51 & 0.28 & 0.80 & 0.41 & 0.27 \\
\hline \multirow[t]{2}{*}[\mathrm{Os}(\text{phen})_{2}\mathrm{CO}(4-\mathrm{phpy})]{$^{2+}$} & $\begin{array}{l}\text { Response Range } \\
(\mu \mathrm{g} / \mathrm{mL})\end{array}$ & $0.5-14$ & $1-18$ & $0.5-13$ & $2-16$ & $0.5-15$ & $0.5-10$ \\
\hline & Linear range Slope & 0.15 & 0.20 & 0.18 & 0.15 & 0.28 & 0.14 \\
\hline
\end{tabular}




\section{Conclusion}

In summary, the two newly synthesized osmium(II) carbonyl complexes have moderate luminescence emission in the visible region, and their emission are highly (5 - 11 times) enhanced by polyanions such as DNA, heparin and carrageenan in ethanol solutions with a blue shift in the emission maximum. UV-Vis spectroscopy reveals that there are small absorbance band changes in the $\pi$ to $\pi^{*}$ and MLCT bands indicating interaction exists between the polyanions and the metal complexes. The high luminescence enhancement of the complexes in ethanol solution by the polyanions may be largely due to the formation of ion-pairs between the polyanion and the complexes, which prevented the ethanol molecular quenching. These enhancements are reproducible and can be utilized to detect the polyanion concentration in the microgram $/ \mathrm{mL}$ range.

\section{Acknowledgements}

This work is supported by St. John's University. EW thanks the writing center at SJU for facilitating the completion of the manuscript.

\section{Conflicts of Interest}

The authors declare no conflicts of interest regarding the publication of this paper.

\section{References}

[1] Wang, J. (2000) Survey and Summary: From DNA Biosensors to Gene Chips. Nucleic Acids Research, 28, 3011-3016. https://doi.org/10.1093/nar/28.16.3011

[2] Huanga, R., Hea, N. and Li, Z. (2018) Recent Progresses in DNA Nanostructure-Based Biosensors for Detection of Tumor Markers. Biosensors and Bioelectronics, 109, 27-34. https://doi.org/10.1016/j.bios.2018.02.053

[3] Reyes, J.B., Kuimova, M.K. and Vilar, R. (2021) Metal Complexes as Optical Probes for DNA Sensing and Imaging. Current Opinion in Chemical Biology, 61, 179-190. https://doi.org/10.1016/j.cbpa.2021.02.007

[4] Hirsh, J., Raschke, C.R., Warkentin, T.E., Dalen, J.E., Deykin, D. and Poller, L. (1992) Heparin: Mechanism of Action, Pharmacokinetics, Dosing Considerations, Monitoring, Efficacy, and Safety. Chest, 102, 258S-275S. https://doi.org/10.1378/chest.108.4_Supplement.258S

[5] Guerrini, M., Beccati, D., Shriver, Z., Naggi, A., Viswanathan, K., Bisio, A., et al. (2008) Oversulfated Chondroitin Sulfate Is a Contaminant in Heparin Associated with Adverse Clinical Events. Nature Biotechnology, 26, 669-675. https://doi.org/10.1038/nbt1407

[6] Bromfield, S.M., Wilde, E. and Smith, D.K. (2013) Heparin Sensing and Binding-Taking Supramolecular Chemistry towards Clinical Applications. Chemical Society Reviews, 42, 9184-9195. https://doi.org/10.1039/C3CS60278H

[7] Campo, V.L., Kawano, D.F., da Silva Jr., D.B. and Carvalho, I. (2009) Carrageenans: Biological Properties, Chemical Modifications and Structural Analysis-A Review. Carbohydrate Polymers, 77, 167-180. https://doi.org/10.1016/j.carbpol.2009.01.020

[8] Necas, J. and Bartosikova, L. (2013) Carrageenan: A Review. Veterinarni Medicina, 
58, 187-205. https://doi.org/10.17221/6758-VETMED

[9] Barton, J.K., Danishefsky, A.T. and Goldberg, J.M. (1984) Tris-(phenanthroline)ruthenium(II): Stereoselectivity in Binding to DNA. Journal of the American Chemical Society, 106, 2172-2176. https://doi.org/10.1021/ja00319a043

[10] Friedman, A.E., Chambron, J.C., Sauvage, J.P., Turro, N.J. and Barton, J.K. (1990) A Molecular Light Switch for DNA: Ru(bpy $)_{2}(\mathrm{dppz})^{2+}$. Journal of the American Chemical Society, 112, 4960-4962. https://doi.org/10.1021/ja00168a052

[11] Ling, L.-S., He, Z.-K., Song, G.-W., Zeng, Y.-E, Wang, C., Bai, C.-L., Chen, X.-D. and Chen, P. (2001) High Sensitive Determination of DNA by Use of Molecular "Light Switch" Complex of Ru(phen $)_{2}(\mathrm{dppx})^{2+}$. Analytica Chimica Acta, 436, 207-214. https://doi.org/10.1016/S0003-2670(01)00922-9

[12] Salem, A.A. (2006) Fluorimetric Determinations of Nucleic Acids Using Iron, Osmium and Samarium Complexes of 4,7-diphenyl-1,10-phenanthroline. Spectrochimica Acta Part A, 65, 235-248. https://doi.org/10.1016/j.saa.2005.10.037

[13] Liu, W., Shen, Y.-M., Li, Z.-X., Zhong, X., Chen, Y.-D. and Zhang, S.-B. (2015) Study on DNA Binding Behavior and Light Switch Effect of New Coumarin-Derived Ru(II) Complexes. Spectrochimica Acta Part A, 149, 150-156. https://doi.org/10.1016/j.saa.2015.04.063

[14] Mardanya, S., Karmakar, S., Maity, D. and Baitalik, S. (2015) Ruthenium(II) and Osmium(II) Mixed Chelates Based on Pyrenyl-Pyridylimidazole and 2,2'-bipyridine Ligands as Efficient DNA Intercalators and Anion Sensors. Inorganic Chemistry, 54, 513-526. https://doi.org/10.1021/ic502271k

[15] Boynton, A.N., Marcelis, L. and Barton, J.K. (2016) $\left[\mathrm{Ru}-\left(\mathrm{Me}_{4} \mathrm{phen}\right)_{2}(\mathrm{dppz})\right]^{2+}$, a Light Switch for DNA Mismatches. Journal of the American Chemical Society, 138, 5020-5023. https://doi.org/10.1021/jacs.6b02022

[16] Boynton, A.N., Marcélis, L., McConnell, A.J. and Barton, J.K. (2017) A Ruthenium(II) Complex as a Luminescent Probe for DNA Mismatches and Abasic Sites. Inorganic Chemistry, 56, 8381-8389.

https://doi.org/10.1021/acs.inorgchem.7b01037

[17] Li, B., Zhou, X., Liu, H., Deng, H., Huang, R. and Xing, D. (2018) Simultaneous Detection of Antibiotic Resistance Genes on Paper-Based Chip Using $\left[\mathrm{Ru}(\mathrm{phen})_{2} \mathrm{dppz}\right]^{2+}$ Turn-on Fluorescence Probe. ACS Applied Materials \& Interfaces, 10, 4494-4501. https://doi.org/10.1021/acsami.7b17653

[18] Zhang, P., Wang, Y., Qiu, K., Zhao, Z., Hu, R., He, C., Zhang, Q. and Chao, H. (2017) A NIR Phosphorescent Osmium(II) Complex as a Lysosome Tracking Reagent and Photodynamic Therapeutic Agent. Chemical Communications, 53, 12341 12344. https://doi.org/10.1039/C7CC07776A

[19] Shun, J., Leung, P.K.-K. and Lo, K.K.-W. (2019) Luminescent Ruthenium(II) Polypyridine Complexes for a Wide Variety of Biomolecular and Cellular Applications. Inorganic Chemistry, 58, 2231-2247. https://doi.org/10.1021/acs.inorgchem.8b02979

[20] Nabiyeva, T., Marschner, C. and Blom, B. (2020) Synthesis, Structure and Anti-Cancer Activity of Osmium Complexes Bearing $\pi$-Bound Arene Substitutuents and Phosphane Co-Ligands: A Review. European Journal of Medicinal Chemistry, 201, Article ID: 112483. https://doi.org/10.1016/j.ejmech.2020.112483

[21] Erkkila, K.E., Odom, D.T. and Barton, J.K. (1999) Recognition and Reaction of Metallointercalators with DNA. Chemical Society Reviews, 99, 277-2796. https://doi.org/10.1021/cr9804341

[22] Lin, H.K. and Sadler, P.J. (2011) Metal Complexes as DNA Intercalators. Accounts 
of Chemical Research, 44, 349-359. https://doi.org/10.1021/ar100140e

[23] Komor, A.C. and Barton, J.K. (2013) The Path for Metal Complexes to a DNA Target. Chemical Communications, 49, 3617-3630. https://doi.org/10.1039/C3CC00177F

[24] Zeng, L., Gupta, P., Chen, Y., Wang, E., Ji, L., Chao, H. and Chen, Z.-S. (2017) The Development of Anticancer Ruthenium(II) Complexes: From Single Molecule Compounds to Nanomaterials. Chemical Society Reviews, 46, 5711-5804. https://doi.org/10.1039/C7CS00195A

[25] Cheng, T.-T., Yao, J.-J., Gao, X., Sun, W., Shi, S. and Yao, T.-M. (2013) A New Fluorescence "Switch on" Assay for Heparin Detection by Using a Functional Ruthenium Polypyridyl Complex. Analyst, 138, 3483-3489.

https://doi.org/10.1039/C3AN00242J

[26] Xie, Y., Lei, Y., Shah, S., Wu, H., Wu, J., Megehee, E. and Wang, E. (2013) Investigation of Luminescence Characteristics of Osmium(II) Complexes in the Presence of Heparin Polyanions. International Journal of Analytical Chemistry, 2013, Article ID: 419716. https://doi.org/10.1155/2013/419716

[27] Wu, H., Wu, J., Saez, C., Campana, M., Megehee, E. and Wang, E. (2013) Study of Luminescence Osmium Complex Response to Macromolecular Polyanions for the Detection of Heparin and Chondroitin Sulfate in Biomedical Preparations. Analytica Chimica Acta, 804, 221-227. https://doi.org/10.1016/j.aca.2013.10.028

[28] Piotrowski, C. (2017) Synthesis, Comparison, and Characterization of bis-diiminecarbonyl-osmium(II) Complexes upon Variation of the Sixth Ligand. Master Thesis, St. John's University, Queens, NY. 